\title{
Two New Species of Dicyema (Dicyemida: Dicyemidae) from Amphioctopus areolatus (Mollusca: Cephalopoda: Octopodidae)
}

\author{
Hidetaka Furuya \\ Department of Biology, Graduate School of Science, Osaka University, \\ 1-1 Machikaneyama, Toyonaka, Osaka, 560-0043 Japan \\ E-mail: hfuruya@bio.sci.osaka-u.ac.jp
}

(Received 5 August 2005; Accepted 13 March 2006)

\begin{abstract}
Two new species of dicyemid mesozoan are described from Amphioctopus areolatus (de Haan, 1840) collected off Irino in Tosa Bay, southern Shikoku, and off Akashi in Osaka Bay, Honshu, Japan. Dicyema balanocephalum sp. nov. is a species of medium size that reaches about $1500 \mu \mathrm{m}$ in length. The vermiform stages are characterized by 19-21 peripheral cells, an elongate calotte, and an axial cell that extends to the base of the propolar cells. Infusoriform embryos consist of 37 cells; two nuclei are present in each urn cell, and the refringent bodies are solid. Dicyema leiocephalum sp. nov. is a species of medium size that reaches about $2000 \mu \mathrm{m}$ in length. The vermiform stages are characterized by 22 peripheral cells, a conical, smooth-surfaced calotte, and an axial cell that extends to the base of the propolar cells. Infusoriform embryos consist of 37 cells; two nuclei are present in each urn cell, and the refringent bodies are solid. This is the first report of dicyemids in $A$. areolatus.
\end{abstract}

Key Words: cephalopods, dicyemids, infusoriform embryos, mesozoans, parasites, renal organs, Amphioctopus areolatus, vermiform embryos.

\section{Introduction}

In Japan the first record of dicyemids was published by Nouvel and Nakao (1938). They described Dicyema misakiense Nouvel and Nakao, 1938 from Octopus vulgaris Lamarck, 1798, and D. orientale Nouvel and Nakao, 1938 from Sepioteuthis lessoniana Lesson, 1830. Nouvel (1947) later described D. acuticephalum Nouvel, 1947 from $O$. vulgaris and identified a dicyemid from Sepia esculenta Hoyle, 1885 as Pseudicyema truncatum Whitman, 1883, which had been described earlier in Europe. Subsequently, two dicyemids, D. japonicum Furuya and Tsuneki, 1992 and $D$. clavatum Furuya and Koshida, 1992, were described from O. vulgaris and Callistoctopus minor (Sasaki, 1920), respectively (Furuya et al. 1992a). Furuya (1999) later reported 14 new species of dicyemid from six cephalopod species caught off the coasts of Japan: Amphioctopus fangsiao (d'Orbigny, 1840), Callistoctopus minor, Octopus hongkongensis Hoyle, 1885, Enteroctopus dofleini (Wülker, 1910), Sepia esculenta, and $S$. lycidas Gray, 1849. More recently, a new dicyemid was described from Sepioteuthis lessoniana by Furuya and Tsuneki (2005), three new dicyemids from Amphioctopus kagoshimensis (Ortmann, 1888) by Furuya (2005), and three new di- 
cyemids from $A$. fangsiao by Furuya (2006).

In this paper two new species in the genus Dicyema are described from Amphioctopus areolatus (de Haan, 1840) collected off Irino in Tosa Bay, Shikoku, and off Akashi in Osaka Bay, Honshu. These two species, the existence of which was first noted by Furuya and Tsuneki (2003), are the first dicyemids to be described from $A$. areolatus.

\section{Materials and Methods}

Forty-eight individuals of Amphioctopus areolatus obtained from fishermen were examined for dicyemids from March, 2001, to January, 2005. The size, sex, and locality of each octopus are indicated in Table 1.

When dicyemids were detected in the kidney of a host cephalopod, small pieces of renal appendages with attached dicyemids were removed and smeared on glass slides. The smears were fixed immediately in Bouin's fluid for $24 \mathrm{hr}$ and then stored in $70 \%$ ethyl alcohol before staining. Most slides were stained in Ehrlich's hematoxylin and counterstained in eosin. Stained smears were mounted using Entellan (Merck). Dicyemids were observed with a light microscope (Olympus BH-2) at magnifications up to $2000 \times$. Measurements and drawings were made with the aid of an ocular micrometer and a drawing tube (Olympus U-DA).

Nouvel (1948), Short and Damian (1966), Furuya et al. (1992b, 1997), and Furuya (1999) give the terminology for cell names used in the descriptions of infusoriform larvae.

Syntypes of the dicyemids are deposited in the Osaka University Museum, Toyonaka, Osaka, Japan (OUM), the Santa Barbara Museum of Natural History, Santa Barbara, California, USA (SBMNH), and in the author's collection. The host octopuses of the syntypes of the two new dicyemid species are deposited in the OUM.

Abbreviations in figures: A, apical cell; AG, agamete (axoblast); AI, apical internal cell; $\mathrm{AL}$, apical internal cell; $\mathrm{AX}$, axial cell; $\mathrm{C}$, couvercle cell; $\mathrm{CA}$, capsule cell; CL, calotte; D, diapolar cell; DC, dorsal caudal cell; DI, dorsal internal cell; DV, developing vermiform embryo; E, enveloping cell; G, germinal cell; I, infusoriform embryo; L, lateral cell; LC, lateral caudal cell; M, metapolar cell; MD, median dorsal cell; NI, nucleus of infusorigen; O, oogonium; $\mathrm{P}$, propolar cell; PA, parapolar cell; PD, paired dorsal cell; PN, paranucleus; PO, primary oocyte; PVL, posteroventral lateral cell; R, refringent body; S, spermatogonium; SP, sperm; U, urn cell; UC, urn cavity; UP, uropolar cells; VC, ventral caudal cell; VI, ventral internal cell; V1, first ventral cell; V2, second ventral cell; V3, third ventral cell.

\section{Taxonomy}

Dicyema balanocephalum sp. nov.

(Figs 1, 2, Tables 1, 2)

Diagnosis. Medium-sized dicyemids, body lengths typically not exceeding $1500 \mu \mathrm{m}$. Peripheral cell number of vermiform stages (i.e., vermiform embryo, ne- 
Table 1. Dicyemid species from the octopus Amphioctopus areolatus.

\begin{tabular}{|c|c|c|c|c|c|}
\hline $\begin{array}{l}\text { Host } \\
\text { no. }\end{array}$ & $\begin{array}{l}\mathrm{ML}^{1} \\
(\mathrm{~mm})\end{array}$ & $\operatorname{Sex}^{2}$ & Locality $^{3}$ & $\begin{array}{c}\text { Date of } \\
\text { examination }\end{array}$ & Dicyemids \\
\hline AR687 & 55 & $q$ & 1 & 07 Jan. 2001 & D. balanocephalum $+D$. leiocephalum \\
\hline AR688 & 45 & q & 1 & 07 Jan. 2001 & None \\
\hline AR701 & 48 & $q$ & 1 & 02 Apr. 2001 & D. balanocephalum \\
\hline AR702 & 52 & q & 1 & 02 Apr. 2001 & None \\
\hline AR703 & 47 & q & 1 & 02 Apr. 2001 & D. balanocephalum \\
\hline AR704 & 50 & $q$ & 1 & 02 Apr. 2001 & None \\
\hline AR705 & 46 & $q$ & 1 & 02 Apr. 2001 & D. balanocephalum \\
\hline AR706 & 48 & q & 1 & 02 Apr. 2001 & D. balanocephalum \\
\hline AR707 & 55 & $\delta$ & 1 & 02 Apr. 2001 & D. balanocephalum $+D$. leiocephalum \\
\hline AR708 & 53 & q & 1 & 02 Apr. 2001 & D. balanocephalum \\
\hline AR709 & 38 & $q$ & 1 & 02 Apr. 2001 & D. balanocephalum \\
\hline AR710 & 55 & $q$ & 1 & 02 Apr. 2001 & None \\
\hline AR711 & 56 & q & 1 & 02 Apr. 2001 & None \\
\hline AR712 & 44 & 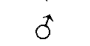 & 1 & 02 Apr. 2001 & D. leiocephalum \\
\hline AR713 & 45 & $q$ & 1 & 02 Apr. 2001 & D. balanocephalum \\
\hline AR714 & 57 & 우 & 1 & 02 Apr. 2001 & None \\
\hline AR715 & 50 & q & 1 & 02 Apr. 2001 & D. leiocephalum \\
\hline AR716 & 60 & q & 1 & 02 Apr. 2001 & None \\
\hline AR717 & 42 & $q$ & 1 & 02 Apr. 2001 & D. leiocephalum \\
\hline AR718 & 46 & q & 1 & 02 Apr. 2001 & D. balanocephalum $+D$. leiocephalum \\
\hline AR760 & 65 & q & 1 & 03 Apr. 2001 & $D$. balanocephalum + D. leiocephalum \\
\hline AR761 & 62 & q & 1 & 03 Apr. 2001 & D. balanocephalum \\
\hline $\mathrm{AR} 762^{\mathrm{a}}$ & 43 & $\delta$ & 1 & 03 Apr. 2001 & D. leiocephalum \\
\hline AR763 & 42 & $\delta$ & 1 & 03 Apr. 2001 & D. leiocephalum \\
\hline AR764 & 50 & q & 1 & 03 Apr. 2001 & D. balanocephalum \\
\hline AR765 & 38 & $\delta$ & 1 & 03 Apr. 2001 & D. leiocephalum \\
\hline AR766 & 40 & $q$ & 1 & 03 Apr. 2001 & D. leiocephalum \\
\hline AR767 & 51 & 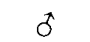 & 1 & 03 Apr. 2001 & D. leiocephalum \\
\hline AR768 & 45 & o & 1 & 03 Apr. 2001 & None \\
\hline AR769 & 45 & 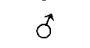 & 1 & 03 Apr. 2001 & D. leiocephalum \\
\hline AR770 & 38 & $\delta$ & 1 & 03 Apr. 2001 & D. leiocephalum \\
\hline AR771 & 36 & $\delta$ & 1 & 03 Apr. 2001 & D. leiocephalum \\
\hline AR772 & 54 & 우 & 1 & 03 Apr. 2001 & D. leiocephalum \\
\hline AR850 & 46 & $\delta$ & 2 & 14 Feb. 2003 & D. balanocephalum \\
\hline AR851 & 45 & $q$ & 2 & 14 Feb. 2003 & D. leiocephalum \\
\hline AR1130 & 47 & $\sigma^{*}$ & 2 & 14 Jan. 2005 & D. leiocephalum \\
\hline AR1131 & 48 & $\hat{\sigma}$ & 2 & 14 Jan. 2005 & D. leiocephalum \\
\hline AR1132 & 40 & $\delta$ & 2 & 14 Jan. 2005 & None \\
\hline AR1133 & 43 & $0^{*}$ & 2 & 14 Jan. 2005 & None \\
\hline AR1134 & 41 & $q$ & 2 & 14 Jan. 2005 & None \\
\hline AR1135 & 37 & o & 2 & 14 Jan. 2005 & None \\
\hline AR1136 & 38 & $\sigma^{*}$ & 2 & 14 Jan. 2005 & None \\
\hline AR1137 & 35 & $q$ & 2 & 14 Jan. 2005 & D. leiocephalum \\
\hline AR1188 & 41 & $\delta$ & 2 & 21 Jan. 2005 & None \\
\hline AR1189 & 42 & $\delta$ & 2 & 21 Jan. 2005 & None \\
\hline AR1267 & 40 & $\delta$ & 2 & 26 Jan. 2005 & None \\
\hline AR1268 & 39 & 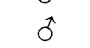 & 2 & 26 Jan. 2005 & None \\
\hline AR1269 & 38 & $\sigma^{\pi}$ & 2 & 26 Jan. 2005 & None \\
\hline
\end{tabular}

${ }^{1}$ Dorsal mantle length.

${ }^{2}$ All specimens were mature.

${ }^{3}$ 1, Tosa Bay (Shikoku); 2, Osaka Bay (Honshu).

a The host (symbiotype) of the syntypes of $D$. leiocephalum.

${ }^{\mathrm{b}}$ The host (symbiotype) of the syntypes of $D$. balanocephalum. 

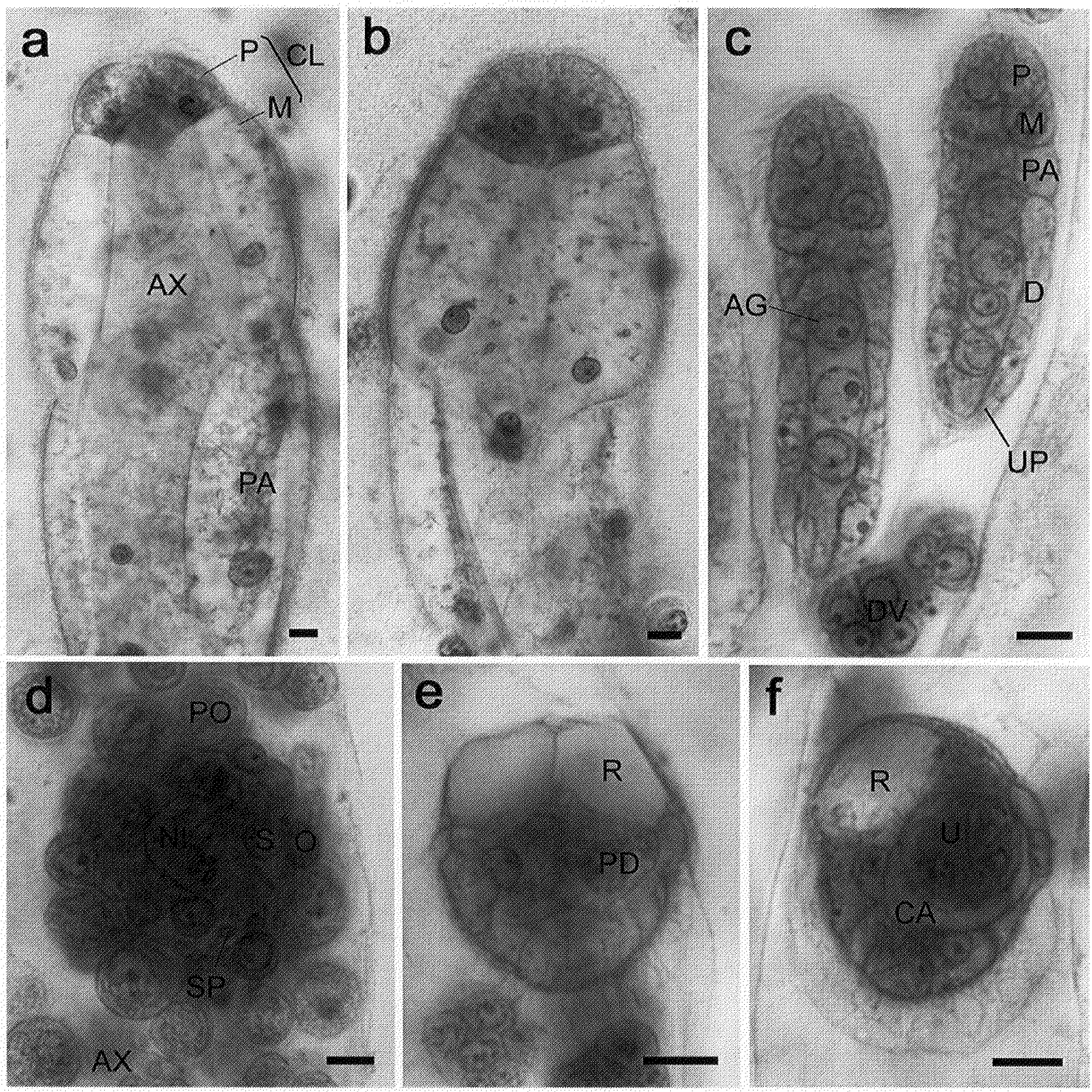

Fig. 1. Dicyema balanocephalum sp. nov, syntype specimens on slide OUM-ME-00009. a, Nematogen, anterior region; $\mathrm{b}$, rhombogen, anterior region; $\mathrm{c}$, vermiform embryos within axial cell; d, infusorigen; e, $f$, infusoriform embryos, horizontal section (e) and sagittal section ( $f$ ). Scale bars: $5 \mu \mathrm{m}$. Abbreviations as in "Materials and Methods".

matogen, and rhombogen) 19-21, i.e., 4 propolars, 4 metapolars, and 11-13 trunk cells. Calotte relatively large, elongate. Infusoriform embryos consisting of 37 cells; urn cells with 2 nuclei each.

Description. Nematogens (Figs 1a, 2a, c). Body slender; lengths ranging from 700 to $1500 \mu \mathrm{m}$, widths from 60 to $80 \mu \mathrm{m}$. Peripheral cell number $19-21$, i.e., 4 propolars, 4 metapolars, 2 parapolars, 7-9 diapolars, and 2 uropolars. Calotte bluntly rounded, elongate (Figs 1a, 2c). Cilia on calotte short, about $3 \mu \mathrm{m}$ long, oriented forwards. Cytoplasm of propolar cells stained with hematoxylin, but metapolar cells not stained (Fig. 1a). Propolar cells and their nuclei smaller than metapolar cells and their nuclei, respectively. Trunk mostly uniform in width; trunk cells 
a

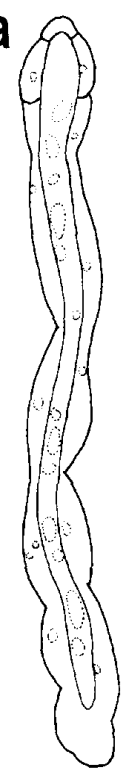

$a b$

I $10 \mu \mathrm{m}$ $\mathrm{b}$

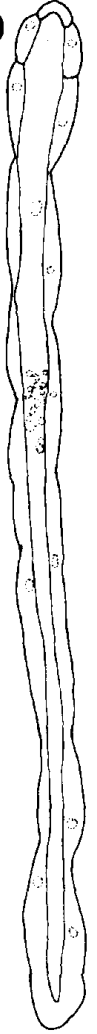

C

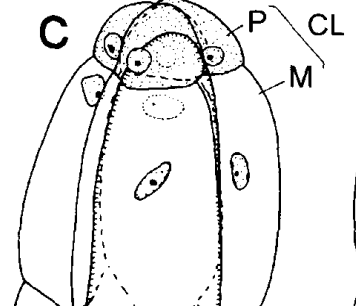

PA

(c)
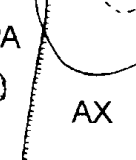

$\mathrm{AX}$

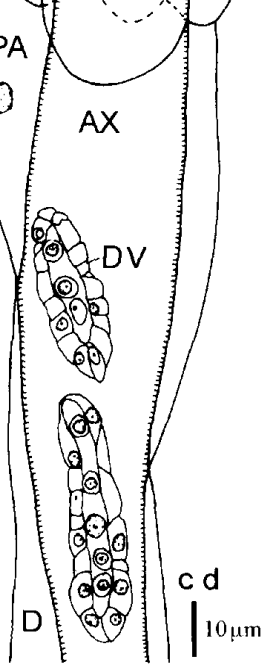

$\mathrm{d}$

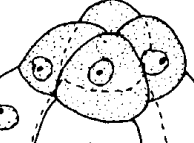

0

0

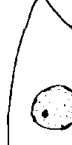

.

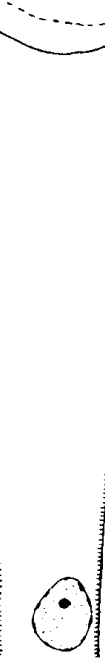

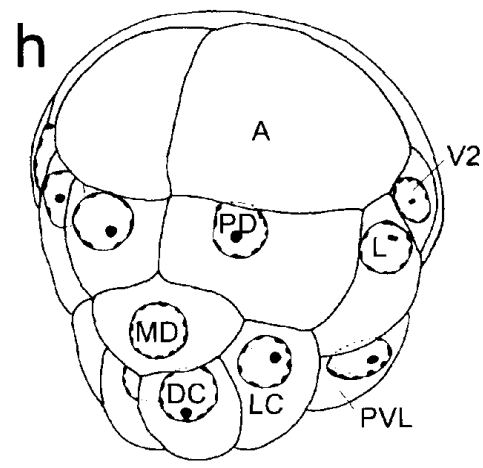
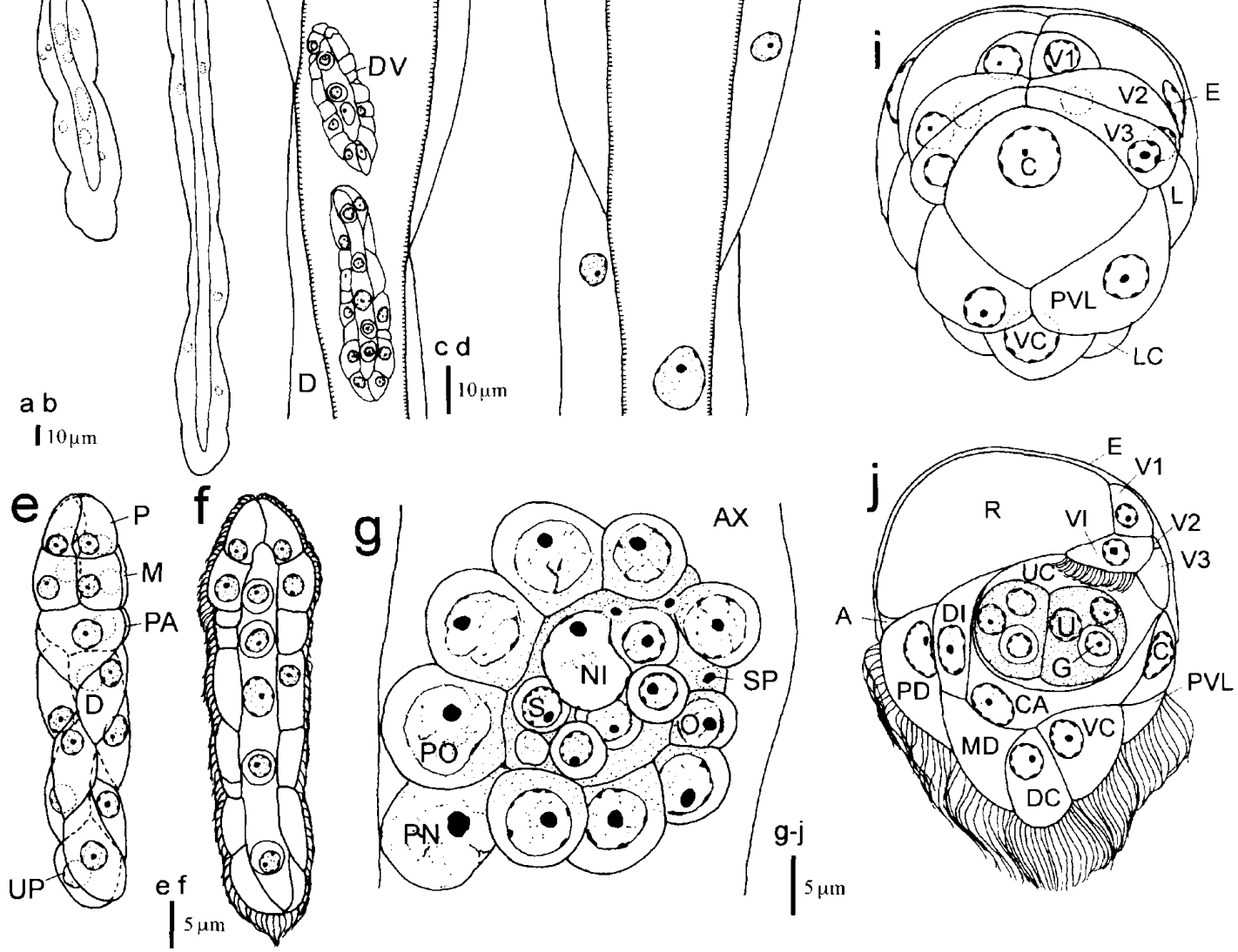

Fig. 2. Dicyema balanocephalum sp. nov., syntype specimens on slide OUM-ME-00009. a, Nematogen, entire; b, rhombogen, entire; c, nematogen, anterior region; d, rhombogen, anterior region; e-g, vermiform embryo within axial cell, cilia omitted (e), optical section (f), and infusorigen (g); $h-j$, infusoriform embryos, dorsal view ( $h$; cilia omitted), ventral view (i; cilia omitted), and sagittal section (j). Abbreviations as in "Materials and Methods".

arranged in opposed pairs. Axial cell cylindrical, rounded anteriorly, extending forward to base of propolar cells (Fig. 1a). In axial cell of large individuals, 20-50 vermiform embryos present. Accessory nuclei occasionally seen in peripheral trunk cells.

Vermiform embryos (Figs 1c, 2e, f). Full-grown vermiform embryos small; lengths ranging from 40 to $60 \mu \mathrm{m}$, widths from 10 to $13 \mu \mathrm{m}$; peripheral cell numbers 19-21 (Table 2). Anterior end of calotte tapered anteriorly, bluntly rounded at tip. 
Trunk cells arranged in opposed pairs. Axial cell rounded anteriorly, extending forward to base of propolar cells. Axial cell nucleus typically located in center of axial cell. Axial cell of full-grown embryos containing 2-5 agametes.

Rhombogens (Figs 1b, 2b, d). Generally similar to nematogens in shape and body proportions; lengths ranging from 700 to $1500 \mu \mathrm{m}$, widths from 60 to $80 \mu \mathrm{m}$. Peripheral cell numbers 19-21 (Table 2). Calotte elongate, as in nematogens. Shape and anterior extent of axial cell similar to those of nematogens. Number of infusorigens present in axial cell 1-3; in axial cell of large individuals, 20-40 infusoriform embryos typically present. Accessory nuclei occasionally present in peripheral cells.

Infusorigens (Figs 1d, 2g). Large. Axial cell of infusorigens usually elliptical in shape, ranging from 20 to $30 \mu \mathrm{m}$ in long diameter. In mature infusorigens $(n=20)$, number of external cells (oogonia and primary oocytes) 38-71 (mode 52), number of internal cells (spermatogonia, primary spermatocytes, and secondary spermatocytes) 24-45 (mode 34), and number of sperm 12-84 (mode 39). Diameter of fertilized eggs $8.6 \mu \mathrm{m}$; diameter of sperm $1.4 \mu \mathrm{m}$.

Infusoriform embryos (Figs $1 \mathrm{e}, \mathrm{f}, 2 \mathrm{~h}-\mathrm{j}$ ). Ovoid, bluntly pointed posteriorly. In full-grown embryos $(n=50)$, length (excluding cilia) $21.3 \pm 1.4 \mu \mathrm{m}$ (mean \pm S.D.), length-width-height ratio $1: 0.83: 0.80$. Cilia at posterior end $6.0 \mu \mathrm{m}$ long. Refringent bodies present, solid, occupying anterior $40 \%$ of embryo length when viewed laterally (Fig. 1f). Cilia of ventral internal cells projecting into urn cavity (Fig. 2j). Cytoplasm of dorsal internal cells transparent. Full-grown infusoriform embryos $(\mathrm{n}=50)$ consisting of 37 cells, i.e., 33 somatic and 4 germinal cells. Somatic cells of several types: external cells covering large part of anterior and lateral surfaces of embryo (2 enveloping cells); external cells with cilia on external surfaces (2 paired dorsal cells, 1 median dorsal cell, 2 dorsal caudal cells, 2 lateral caudal cells, 1 ventral caudal cell, 2 lateral cells, and 2 posteroventral lateral cells); external cells with refringent bodies ( 2 apical cells); external cells without cilia ( 2 first ventral cells, 2 second ventral cells, 2 third ventral cells, and 1 couvercle cell); internal cells with cilia ( 2 ventral internal cells); and internal cells without cilia ( 2 dorsal internal cells, 2 capsule cells, and 4 urn cells). Each urn cell containing 1 germinal cell plus 2 nuclei (Fig. 2j). Nuclei of second ventral cells pycnotic. All somatic nuclei typically becoming pycnotic as infusoriform embryos mature.

Type series. Syntypes: OUM-ME-00009 (1 slide); SBMNH-359814 (1 slide); No. HF-AR764 (1 slide) (author's collection).

Type locality. Japan, Shikoku, Kochi Prefecture, Tosa Bay, off Irino, $32^{\circ} 55^{\prime} \mathrm{N}$, $137^{\circ} 10^{\prime} \mathrm{E}$.

Host (symbiotype). Amphioctopus areolatus (Cephalopoda: Octopoda: Octopodidae), mature female, $50 \mathrm{~mm}$ ML (mantle length), OUM-MO-00008 (AR764 in Table 1).

Site of infection. Within renal sacs; anterior ends (calottes) inserted into crypts of the renal appendages.

Prevalence. Dicyemids found in 14 host cephalopods obtained in Tosa Bay (Irino) and Osaka Bay (Akashi), with $29.2 \%$ prevalence among 48 cephalopods examined (see Table 1).

Distribution. Type locality and off Akashi, Osaka Bay, Honshu, Japan.

Etymology. The specific name is an adjective composed of two Greek roots, balanos, meaning "acorn", and -kephalos, meaning "-headed", in reference to the 
Table 2. Number of peripheral cells in two new species of Dicyema.

\begin{tabular}{ccrcc}
\hline & Cell & \multicolumn{3}{c}{ Number of individuals } \\
\cline { 3 - 5 } Species & number & Nematogens & $\begin{array}{c}\text { Vermiform } \\
\text { embryos }\end{array}$ & Rhombogens \\
& 19 & 8 & 4 & 7 \\
Dicyema balanocephalum & 20 & 37 & 39 & 40 \\
& 21 & 5 & 7 & 3 \\
\hline \multirow{2}{*}{ Dicyema leiocephalum } & 21 & 1 & 0 & 3 \\
& 22 & 49 & 50 & 47 \\
\hline
\end{tabular}

characteristic acorn-shaped calotte of the adult stages.

Remarks. Dicyema balanocephalum is very similar to D. dolichocephalum Furuya, 1999, a dicyemid of Callistoctopus minor, in having an elongate calotte (Furuya 1999). However, D. balanocephalum is distinguishable from $D$. dolichocephalum in the maximum body length of vermiform stages $(1500 \mu \mathrm{m}$ vs. $800 \mu \mathrm{m})$, the average length of infusoriform embryos $(21.3 \mu \mathrm{m}$ vs. $28.0 \mu \mathrm{m})$, the size of infusorigens $(10 \mu \mathrm{m}$ vs. $15-20 \mu \mathrm{m}$ in diameter), and the number of peripheral cells (19-21 vs. 18 or 20). Dicyema balanocephalum can be distinguished from all the other species in the genus on the basis of its calotte shape, small propolar cells, long metapolar cells, and number of peripheral cells.

In contrast to the distinct calotte shape, the infusoriform embryos of $D$. balanocephalum are of typical type with respect to cellular composition and cell number (Furuya et al. 2004).

\section{Dicyema leiocephalum sp. nov.}

(Figs 3, 4, Tables 1, 2)

Diagnosis. Medium-sized dicyemids, body lengths typically not exceeding $2000 \mu \mathrm{m}$. Peripheral cell number of vermiform stages (i.e., vermiform embryo, nematogen, and rhombogen) 22, i.e., 4 propolars, 4 metapolars, and 14 trunk cells. Calotte relatively large, conical, smooth-surfaced. Infusoriform embryos consisting of 37 cells; urn cells with 2 nuclei each.

Description. Nematogens (Figs $3 \mathrm{a}, 4 \mathrm{a}, \mathrm{c}$ ). Body slender; lengths ranging from 600 to $2000 \mu \mathrm{m}$, widths from 30 to $70 \mu \mathrm{m}$. Peripheral cell number 22, i.e., 4 propolars, 4 metapolars, 2 parapolars, 10 diapolars, and 2 uropolars. Calotte bluntly rounded, conical, smooth-surfaced (Figs 3a, 4c). Cilia on calotte short, about $3 \mu \mathrm{m}$ long, oriented forwards. Propolar cells and their nuclei smaller than metapolar cells and their nuclei, respectively (Fig. 3a). Trunk mostly uniform in width; trunk cells arranged in opposed pairs. Axial cell cylindrical, rounded anteriorly, extending forward to base of propolar cells (Fig. 4c). In axial cell of large individuals, 12-50 vermiform embryos present. Accessory nuclei seen in peripheral trunk cells.

Vermiform embryos (Figs 3c, 4e, f). Full-grown vermiform embryos mediumsized; lengths ranging from 70 to $110 \mu \mathrm{m}$, widths from 9 to $13 \mu \mathrm{m}$; peripheral cell number 22 (Table 2). Anterior end of calotte tapered anteriorly, bluntly rounded at 

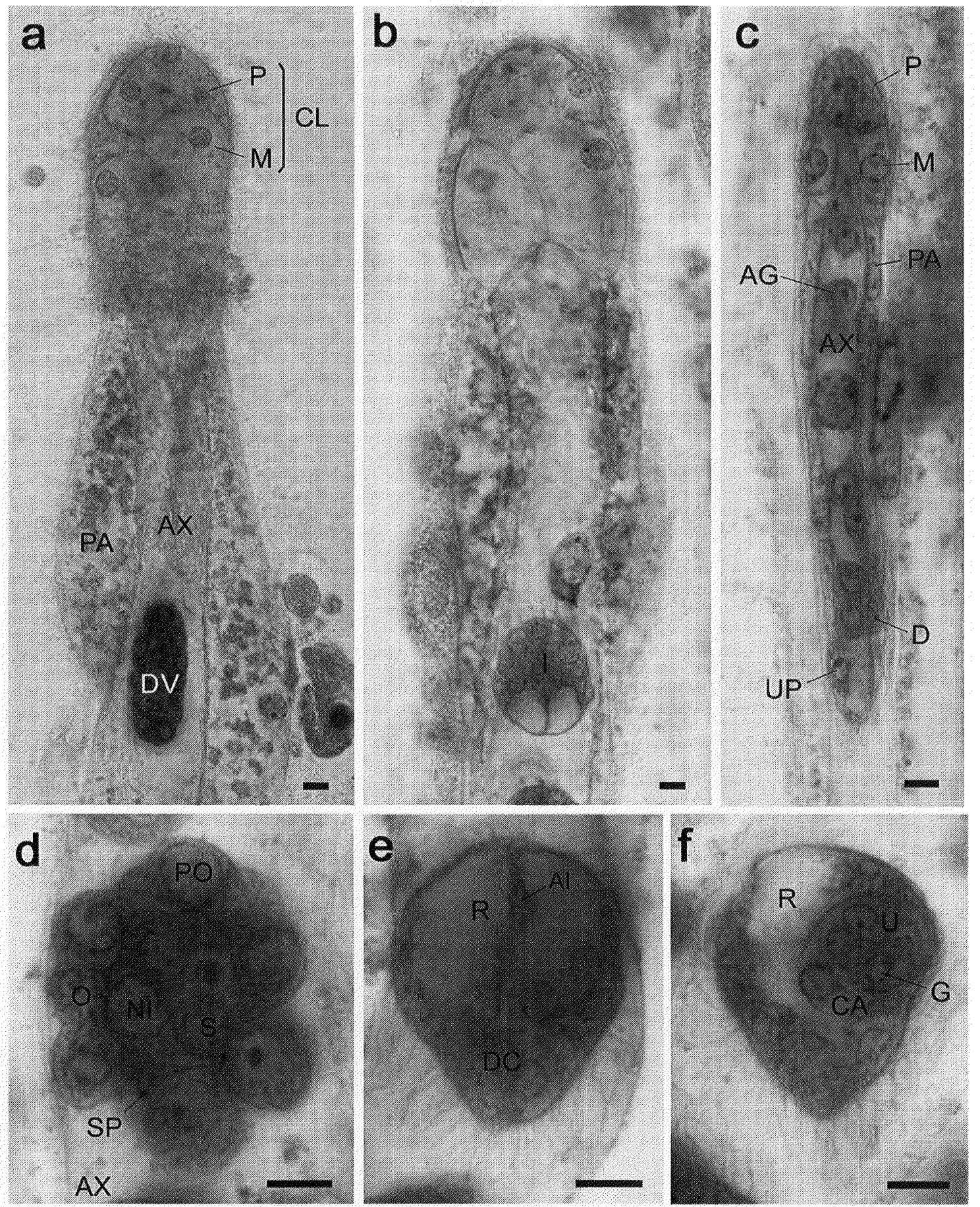

Fig. 3. Dicyema leiocephalum sp. nov., syntype specimens on slide OUM-ME-00010. a, Nematogen, anterior region; $\mathrm{b}$, rhombogen, anterior region; $\mathrm{c}$, vermiform embryo within axial cell; d, infusorigen, e, f, infusoriform embryo, horizontal section (e) and sagittal section (f). Scale bars: $5 \mu \mathrm{m}$. Abbreviations as in "Materials and Methods".

tip. Cytoplasm of propolar cells stained with hematoxylin, but metapolar cells not stained (Fig. 3c). Trunk cells arranged in opposed pairs. Axial cell rounded anteriorly, extending forward to base of propolar cells. Axial cell nucleus typically lo- 

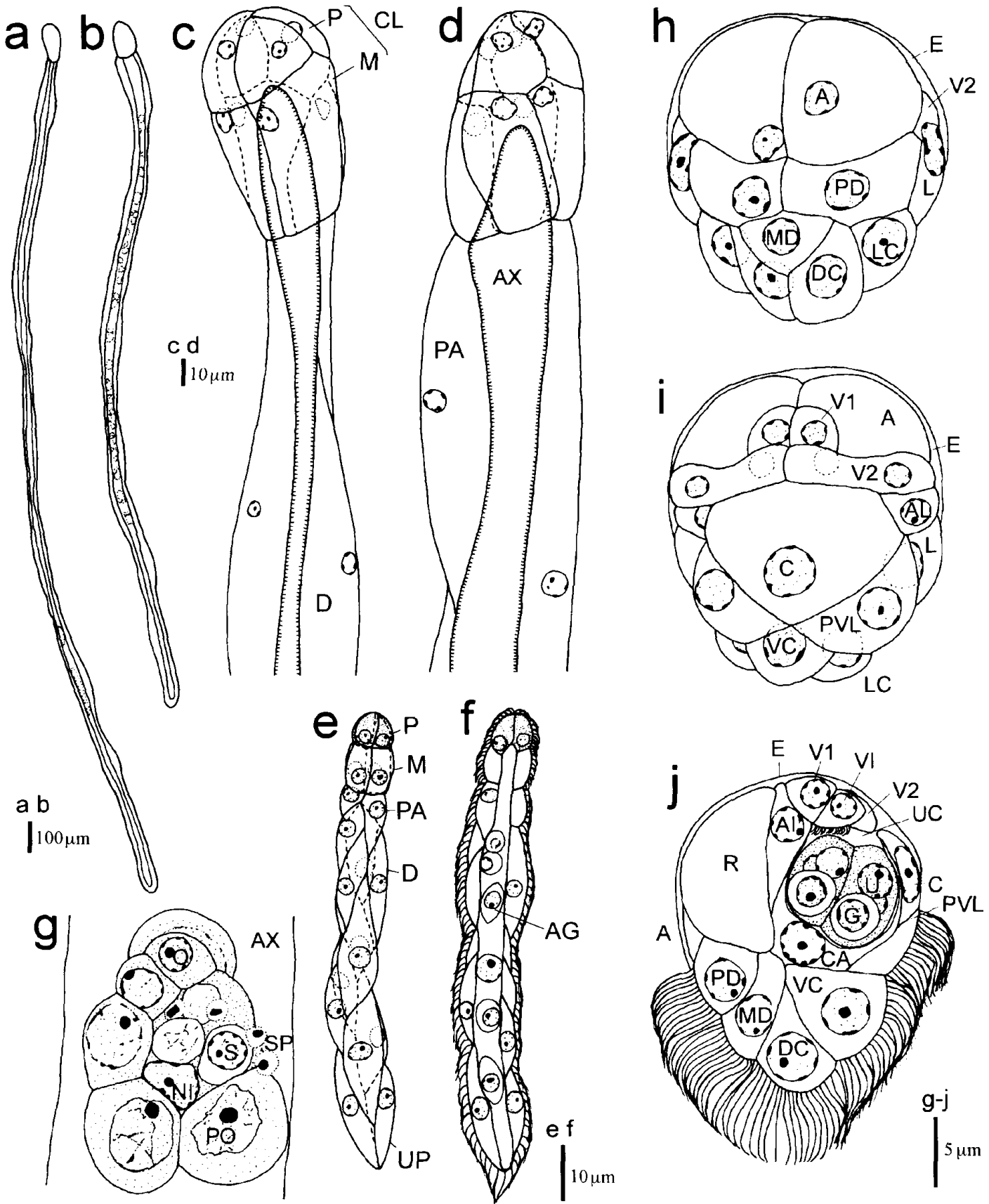

Fig. 4. Dicyema leiocephalum sp. nov., syntype specimens on slide OUM-ME-00010. a, Nematogen, entire; b, rhombogen, entire; c, nematogen, anterior region; d, rhombogen, anterior region; e-g, vermiform embryos within axial cell, cilia omitted (e), optical section (f), and infusorigen (g); h-j, infusoriform embryos, dorsal view (h; cilia omitted), ventral view (i; cilia omitted), and sagittal section (j). Abbreviations as in "Materials and Methods".

cated in center of axial cell. Axial cell of full-grown embryos containing 4-11 agametes, some of latter elliptical (Figs 3c, 4f).

Rhombogens (Figs $3 \mathrm{~b}, 4 \mathrm{~b}, \mathrm{~d}$ ). Slightly stockier than nematogens, otherwise generally similar in shape and body proportions; lengths ranging from 600 to $2000 \mu \mathrm{m}$, 
widths from 30 to $80 \mu \mathrm{m}$. Peripheral cell number typically 22 (Table 2). Calotte conical as in nematogens. Shape and anterior extent of axial cell similar to those of nematogens. Number of infusorigens present in axial cell 1 or 2; in axial cell of large individuals, 10-42 infusoriform embryos typically present. Accessory nuclei present in peripheral cells.

Infusorigens (Figs 3d, 4g). Medium-sized. Axial cell of infusorigens usually rounded, diameter $10-13 \mu \mathrm{m}$. In mature infusorigens $(n=20)$, number of external cells (oogonia and primary oocytes) 6-12 (mode 10), number of internal cells (spermatogonia, primary spermatocytes, and secondary spermatocytes) 3-5 (mode 4), and number of sperm $4-6$ (mode 5). Diameter of fertilized eggs $9.6 \mu \mathrm{m}$; diameter of sperm $1.3 \mu \mathrm{m}$.

Infusoriform embryos (Figs 3e, f, $4 \mathrm{~h}-\mathrm{j}$ ). Ovoid, bluntly pointed posteriorly. In full-grown embryos $(\mathrm{n}=50)$, length (excluding cilia) $22.4 \pm 1.6 \mu \mathrm{m}$ (mean \pm S.D.), length-width-height ratio $1: 0.74: 0.73$. Cilia at posterior end $4.8 \mu \mathrm{m}$ long. Refringent bodies present, solid, occupying anterior $40 \%$ of embryo length when viewed laterally (Figs 3f, 4j). Nuclei of apical internal cells usually visible between refringent bodies (Fig. 3e). Cilia of ventral internal cells projecting into urn cavity (Fig. 4j). Cytoplasm of capsule cells transparent. Full-grown infusoriform embryos $(n=50)$ consisting of 37 cells, i.e., 33 somatic and 4 germinal cells. Somatic cells of several types: external cells covering large part of anterior and lateral surfaces of embryo ( 2 enveloping cells); external cells with cilia on external surfaces ( 2 paired dorsal cells, 1 median dorsal cell, 2 dorsal caudal cells, 2 lateral caudal cells, 1 ventral caudal cell, 2 lateral cells, and 2 posteroventral lateral cells); external cells with refringent bodies ( 2 apical cells); external cells without cilia ( 2 anterior lateral cells, 2 first ventral cells, 2 second ventral cells, and 1 couvercle cell); internal cells with cilia ( 2 ventral internal cells); and internal cells without cilia ( 2 apical internal cells, 2 capsule cells, and 4 urn cells). Each urn cell containing 1 germinal cell plus 2 nuclei (Fig. 4j). Nuclei of second ventral cells pycnotic. All somatic nuclei typically becoming pycnotic as infusoriform embryos mature.

Type series. Syntypes: OUM-ME-00010 (1 slide); SBMNH-359815 (1 slide); No. HF-AR762 (1 slide) (author's collection).

Type locality. Japan, Shikoku, Kochi Prefecture, Tosa Bay, off Irino, $32^{\circ} 55^{\prime} \mathrm{N}$, $137^{\circ} 10^{\prime} \mathrm{E}$.

Host (symbiotype). Amphioctopus areolatus (Cephalopoda: Octopoda: Octopodidae), mature male, $43 \mathrm{~mm}$ ML (mantle length), OUM-MO-00009 (AR762 in Table 1).

Site of infection. Within renal sacs; anterior ends (calottes) inserted into crypts of the renal appendages.

Prevalence. Dicyemids found in 20 host cephalopods obtained in Tosa Bay (Irino) and Osaka Bay (Akashi), with $41.7 \%$ prevalence among 48 cephalopods examined (see Table 1).

Distribution. The type locality and off Akashi, Osaka Bay, Honshu, Japan.

Etymology. The specific name is an adjective composed of two Greek roots, leios, meaning "smooth", and -kephalos, meaning "-headed", in reference to the characteristic smooth-surfaced calotte of the adult stages.

Remarks. Dicyema leiocephalum is characterized by a conical, smoothsurfaced calotte, 22 peripheral cells, and infusoriform embryos lacking dorsal internal cells. In these respects $D$. leiocephalum is easily distinguished from $D$. bal- 
anocephalum.

The size and number of infusorigens are diagnostic characteristics of dicyemid species (Furuya et al. 1993). There is a negative curvilinear relationship between the number of infusorigens per rhombogen and the number of gametes per infusorigen (Furuya et al. 2003b). Two distinct groups of dicyemid species are apparent: (1) those with rhombogens that form a small number of infusorigens that each produces a relatively large number of gametes (up to 70); (2) those with rhombogens that tend to form a large number of infusorigens, each of which produces at most 20 gametes. Rhombogens of $D$. leiocephalum have a small number of mediumsized infusorigens and produce a relatively small number of gametes; thus this species does not belong to either of these two groups. Rhombogens of $D$. balanocephalum have a small number of large-sized infusorigens and produce a relatively large number of gametes; thus this species belongs to the first group.

In cellular composition of the infusoriform embryos, D. leiocephalum is of a particular type that possesses anterior internal cells and lacks dorsal internal cells (Furuya et al. 1997, 2004). In the genus Dicyema, this type of infusoriform embryo has not been reported thus far. In other genera, only infusoriform embryos of Dicyemodeca deca (McConnaughey, 1957) lack the dorsal internal cells (Furuya et al. 2004).

\section{Discussion}

There is considerable taxonomic confusion with regard to the group of small to medium-sized species of Octopus living primarily on substrates of sand or mud in tropical and subtropical waters of the Indo-Pacific (Robson 1929; Huffard and Hochberg 2005; Norman and Hochberg in press). This group consists of two subgroups, an ocellate subgroup including Octopus areolatus and a non-ocellate subgroup including Octopus aegina (Gray, 1849). Huffard and Hochberg (2005) proposed to place these two subgroups in the genus Amphioctopus.

Amphioctopus areolatus inhabits inshore waters and is distributed from the Seto Inland Sea, and Tosa Bay, to the Chinese coast. This octopus is characterized by a pair of bluish-gray ocelli on the web between arms II and III, three dark stripes on the head, and two stripes on the dorsal mantle. Several species of dicyemids have been found in species of Amphioctopus, such as A. aegina from Taiwan (Furuya et al. unpublished), A. kagoshimensis from Japan (Furuya 2005), A. burryi (Voss, 1950) from the Gulf of Mexico (Furuya et al. 2002), and A. fangsiao from Japan (Furuya 1999, 2006). However, dicyemids were not found in an undescribed Amphioctopus from Hawaii (Huffard and Hochberg 2005).

In this study the two new dicyemid species, Dicyema balanocephalum and $D$. leiocephalum, were found in 30 of 48 examined individuals of Amphioctopus areolatus caught in Tosa Bay and Osaka Bay. This data revealed geographical variations in prevalence, $75.8 \%(25 / 33)$ in Tosa Bay and $33.3 \%(5 / 15)$ in Osaka Bay. There is a direct relationship between host size and dicyemid occurrence (Furuya et al. 1992a): smaller or younger cephalopods of a host species generally do not harbor dicyemids. In $A$. areolatus, however, the 18 examined individuals that harbored no dicyemids were medium- and large-sized and the absence of dicyemids in them can not be attributed to host size. 
In cephalopods that harbor two or three dicyemid species in the renal sac, the calotte shapes are typically different from each other (Furuya et al. 2003a). Dicyemids that have similar calotte shapes are very rarely found together in a single host individual. In $A$. areolatus, the calotte shapes of $D$. leiocephalum and $D$. balanocephalum are conical and elongate, respectively, but both shapes fall into the conical category recognized by Furuya et al. (2003a). In accordance with expectations, co-occurrence of the two present dicyemid species was only $13.3 \%(4 / 30)$.

With respect to cellular composition and cell number, the infusoriform embryos of $D$. balanocephalum are of the typical type (Furuya et al. 2004). In contrast, D. leiocephalum is characterized by infusoriform embryos that possess anterior internal cells and lack dorsal internal cells. Infusoriform embryos possessing anterior internal cells have been found in the dicyemids from A. fangsiao, A. kagoshimensis, and Octopus vulgaris in Japan. These Amphioctopus species are closely related to O. vulgaris (Takumiya et al. 2005). I speculate possession of anterior internal cells by infusoriform embryos of dicyemids in these host species may be attributed to the close relationships among the host species.

\section{Acknowledgments}

I would like to express my gratitude to Dr Kazuhiko Tsuneki of Osaka University for his critical reading of the manuscript and valuable advice. I also thank Dr Eric Hochberg for providing me with information on current octopus taxonomy. This study was supported by grants from the Nakayama Foundation for Human Science, the Research Institute of Marine Invertebrates Foundation, and the Japan Society for the Promotion of Science (research grant no. 14540645).

\section{References}

Furuya, H. 1999. Fourteen new species of dicyemid mesozoans from six Japanese cephalopods, with comments on host specificity. Species Diversity 4: 257-319.

Furuya, H. 2005. Three new species of Dicyema (Dicyemida: Dicyemidae) from Octopus kagoshimensis (Mollusca: Cephalopoda: Octopodidae). Species Diversity 10: 231-247.

Furuya, H. 2006. Three new species of dicyemid mesozoans (Phylum Dicyemida) from Amphioctopus fangsiao (Mollusca: Cephalopoda), with comments on the occurrence patterns of dicyemids. Zoological Science 23: 105-119.

Furuya, H., Damian, R. T. and Hochberg, F. G. 2002. A new species of Dicyema (Phylum Dicyemida) from Octopus burryi (Mollusca: Cephalopoda) in the Gulf of Mexico. Journal of Parasitology 88: 325-329.

Furuya, H., Hochberg, F. G. and Tsuneki, K. 2003a. Calotte morphology in the phylum Dicyemida: niche separation and convergence. Journal of Zoology 259: 361-373.

Furuya, H., Hochberg, F. G. and Tsuneki, K. 2003b. Reproductive traits of dicyemids. Marine Biology 142: 693-706.

Furuya, H., Hochberg, F. G. and Tsuneki, K. 2004. Cell number and cellular composition in infusoriform larvae of dicyemid mesozoans (Phylum Dicyemida). Zoological Science 21: 877-889.

Furuya, H. and Tsuneki, K. 2003. Biology of dicyemid mesozoans. Zoological Science 20: 
$519-532$.

Furuya, H. and Tsuneki, K. 2005. A new species of dicyemid mesozoan (Dicyemida: Dicyemidae) from Sepioteuthis lessoniana (Mollusca: Cephalopoda), with notes on Dicyema orientale. Species Diversity 10: 45-62.

Furuya, H., Tsuneki, K. and Koshida, Y. 1992a. Two new species of the genus Dicyema (Mesozoa) from octopuses of Japan with notes on D. misakiense and D. acuticephalum. Zoological Science 9: 423-437.

Furuya, H., Tsuneki, K. and Koshida, Y. 1992b. Development of the infusoriform embryo of Dicyema japonicum (Mesozoa: Dicyemidae). Biological Bulletin 183: 248-257.

Furuya, H., Tsuneki, K. and Koshida, Y. 1993. The development of the hermaphroditic gonad in four species of dicyemid mesozoans. Zoological Science 10: 455-466.

Furuya, H., Tsuneki, K. and Koshida, Y. 1997. Fine structure of a dicyemid mesozoan, Dicyema acuticephalum, with special reference to cell junctions. Journal of Morphology 231 : $297-305$.

Huffard, C. L. and Hochberg, F. G. 2005. Description of a new species of the genus Amphioctopus (Mollusca: Octopodidae) from the Hawai'ian Islands. Molluscan Research 25: 113-128.

Norman, M. D. and Hochberg, F. G. In press. The current state of octopus taxonomy. Phuket Marine Biological Center Special Publication.

Nouvel, H. 1947. Les Dicyémides. $1^{\text {re }}$ partie: systématique, générations, vermiformes, infusorigène et sexualité. Archives de Biologie, Paris 58: 59-220.

Nouvel, H. 1948. Les Dicyémides. $2^{\mathrm{e}}$ partie: infusoriforme, tératologie, spécificité du parasitisme, affinités. Archives de Biologie, Paris 59: 147-223.

Nouvel, H. and Nakao, Y. 1938. Dicyémides du Japon. Bulletin de la Société Zoologique de France 63: 72-80.

Robson, G. C. 1929. A Monograph of the Recent Cephalopoda. Part I. Octopodinae. British Museum (Natural History), London, $236 \mathrm{pp}$.

Short, R. B. and Damian, R. T. 1966. Morphology of the infusoriform larva of Dicyema aegira (Mesozoa: Dicyemidae). Journal of Parasitology 52: 746-751.

Takumiya, M., Kobayashi, M., Tsuneki, K. and Furuya, H. 2005. Phylogenetic relationships among major species of Japanese coleoid cephalopods (Mollusca: Cephalopoda) using three mitochondrial DNA sequences. Zoological Science 22: 147-155. 